\title{
European and Czech Salon Piano Music in the Second Half of the $19^{\text {th }}$ Century
}

\author{
Jana Gajdošíková
}

Salon music has been considered a genre distinguished by a number of standardized features, for example the over-romanticized melodies, superficial virtuosity, extreme dynamic contrasts, pseudo-virtuoso cadenzas, abrupt tempo changes and mass-produced and disseminated musical works. The term musique de salon was used for the first time in 1833 in a French magazine, Le Pianiste. Three year later the term Salonmusik appeared in the German periodical Neue Zeitschrift für Musik.

Salon music originally emerged in Paris around 1830 and from there branched throughout Europe. The reason for this was that Paris became a Mecca of virtuosity where the master pianists of the time lived and worked: Fryderyk Chopin, Franz Liszt, Friedrich Wilhelm Kalkbrenner, Camille Pleyel, Sigismund Thalberg etc. Salon music production tried to copy some virtuoso techniques of their playing but in a very simplified manner. In association with the abovementioned text is apposite to use Schumann's saying that ironically describes salon music production of that time: "das Liszthum ins Kinderleichte". Many favourite pieces have been transcribed and paraphrased on a less demanding level (Edition simplifiées). Not only music dilettantes but also numerous prominent piano composers wrote salon music for profit-making reasons. Among these $19^{\text {th }}$-century composers were Carl Czerny, Carl Cramer, Henry Herz, Theodor Oesten, Gustav Lange, Alexander Gorias, Anton de Kontkis, Lefébure-Wély and Tekla Badarzewska.

The expansion of salon music in the $19^{\text {th }}$ century had a big impact on many extern factors-social, economical and political mostly. The crucial one was a blossoming of the bourgeoisie in 1830-1848; this resulted in the biggest consumer of salon music. Playing the piano became a very fashionable activity. In 1876 Otto Gumprecht wrote in his essay Die Frauen in der Musik that the dowry of each daughter must have been a repertoire of salon literature. The industrial revolution opened up the market to new publishing

\footnotetext{
Andreas Ballstaedt, "Salonmusik", in: Friedrich Blume, Ludwig Finscher (eds.), Die Musik in Geschichte und Gegenwart: allgemeine Enzyklopädie der Musik, Sachteil 8 (Stuttgart, 1998), col. 861.
} 
houses, producers of music instruments and other related sectors. Owning a piano was a must for all well-to-do families. In this connection a pianist and saloniére called Johanna Kinkel said in 1852: "Ein gebildetes Haus, in dem kein Clavier stünde, gälte für eine Unmöglichkeit." 2

Salon music was a highly criticized genre within the $19^{\text {th }}$ century. Among the biggest critics were Robert Schumann, Eduard Hanslick, Richard Wagner, Heinrich Heine, Hector Berlioz and Adolf Bernard Marx. Many of Schumann's pejorative critiques on salon music were written in the periodical Neue Zeitschrift für Musik, for instance the following: "Mit Süssigkeiten, Back-, und Zuckerwerk zieht man keine Kinder zu gesunden Menschen."3 "Hier hőrt das Amt der Kritik auf und es beginnt das der musikalischen Polizei." 4

Opinion of salon music was more positive earlier in the $19^{\text {th }}$ century. In Schumann's classification from 1836 can be found three types of salon music: 1. "gehobene Salonmusik", 2. "virtuose Salonmusik", 3. "romantisierende Salonmusik". ${ }^{5}$ To the $1^{\text {st }}$ category belonged the music of Fryderyk Chopin, to the $2^{\text {nd }}$ the music of Henry Herz and to the $3^{\text {rd }}$ everything which followed romantic tendencies.

The decadence of the salon in the second half of the $19^{\text {th }}$ century is expressed by the following critique written by Louis Elert in 1879: "Wie unser Salon, örtlich gesprochen, meinst eine der Wohnung künstlich abgerungene Stätte ist, so bleibt er auch moralisch ein Durchgangszimmer ohne Behaben und Selbstbestimmung." ${ }^{\prime 6}$ But already in Chopin's time an ambivalency in the quality of salons and its recipients can be found: "Es überrascht dann nicht, daß selbst ein Musiker wie Chopin, der, die Öffentlichkeit scheuend, in den Pariser Salons heimisch war, sich nach einem Bericht Berlioz' erst zum Spiel bewegen ließ, als die lautstarken und gesprächigen Gäste den Salon verlassen hatten.”

Salon and salon piano music experienced a big qualitative change within the $19^{\text {th }}$ century. Originally the instigator of highly intellectual discourses the salon became a pompous institution where music experienced the biggest qualitative decline ever. As Adolf Ruthardt said in 1905, salon music was a fashionable issue which faded out as quickly as fashion itself.

Peter Gradenwitz, Literatur und Musik in geselligem Kreise (Stuttgart, 1991), p. 179.

Eva Fürtinger, Musik in den Salons und in der Geschäftswelt (Vienna, 2004), p. 39.

4 Hans Christoph Worbs, "Salonmusik", in: Carl Dahlhaus (ed.), Studien zur Trivialmusik des 19. Jahrhundert (Regensburg, 1967), p. 124.

$5 \quad$ Imogen Fellinger, "Die Begriffe Salon und Salonmusik in der Musikanschauung des 19. Jahrhunderts”, In: Carl Dahlhaus (ed.), Studien zur Trivialmusik des 19. Jahrhunderts (Regensburg, 1967), p. 134 .

$6 \quad$ Ibid., p. 137.

7 Andreas Ballstaedt, "Salonmusik", in: Friedrich Blume, Ludwig Finscher (eds.), Die Musik in Geschichte und Gegenwart: allgemeine Enzyklopädie der Musik, Sachteil 8 (Stuttgart, 1998), col. 859. 
A connection between salons and salon music in the Czech territory can already be found in the first half of the $19^{\text {th }}$ century. Salon society embraced Václav Jan Tomášek and the young Bedřich Smetana, for example. Smetana worked as a piano teacher in the different bourgeoisie and aristocratic salons.

The importance of piano-playing and the expansion of salon music can be dated from the late 1870s, a fact which is documented by several periodicals. In 1884-1891 Emanuel Binko published the monthly periodical Hudební květy - Měsičník pro zábavu a cvičení pianistü [Musical Flowers - A Monthly Periodical for the Entertainment and Practice of Pianists] which consisted of easily playable piano music. In 1878-1891 he also published the monthly periodical Varytó - časopis pro hudbu a zpěv [Varytó - Magazine for Music and Singing]. From the editorial office of Josef R. Vilímek was issued Humoristické listy [Humorous Letters] and a part of this periodical consisted of attachments which included the music of Dvořák, Smetana, Fibich, Malát etc.

The publishing house of František A. Urbánek (1842-1919) cultivated the most aggressive marketing attitude towards salon music. From 1879 he combined the publishing activities of sheet music on the one hand and the music periodical Dalibor (issued from Urbánek's publishing office in 1879-1927) on the other. In that time Dalibor was the only technical magazine that was interested in the area of classical music. Urbánek used Dalibor to advertise music he published which was mostly composed by Smetana, Fibich, Suk, partly Dvořák but also music written by Czech salon piano composers, for example Josef Nešvera, Jindřich Káan z Albestů, Josef Vrbata, Karel Weis, Richard Kaska, Rudolf Nováček, Bohuslav Jeremiáš, Karel Kovařovic, František Picka, Alois Jiránek, Josefína Brdlíková, Josefína Eiseltová, František Hartl etc. Thanks to Dalibor Urbánek’s publishing house created a hegemony in the area of publishing sheet music.

Besides the official advertising which was found at the end of the magazine Urbánek used "a tacit advertising". In the Musical review section he often reviewed musical pieces that he published and in the Literature section he gave an overview of all the books and musical sheets that were published by different publishers including his own. Every critical eye that scans its particular editions can see that Dalibor was a half-advertising periodical and half-serious music magazine. Its advertising part is targeted to a specific group of music dilettantes.

The advertising section in Dalibor acts today as documentation for that what was published by Urbánek's family in 1879-1927. To catch the consumer's attention different typography, italics, various sizes of letters, frames or picture covers were used for the particular sheet music. Subscribers were attracted by different slogans, for example Hudební dárky vánoční a vůbec sváteční [Christmas and Other Festal Musical Presents], Nejkrásnější dárek krásne naší pleti! [The Most Beautiful Present for Our Beautiful Faces], Překrásne upravené hudební dárky ve skvostných vazbách [Beautifully Selected Musical Presents in Splendid Bindings], Něžné dárky mladým pianistům [Sweet Presents for Young Pianists] etc.

In the publication of sheet music a huge emphasis was put on the cover; this was a common practice throughout the whole of Europe. The easier the salon music compo- 
sition was, the more beautiful, more flowery and more decorative the cover. This can be realized when looking at the contradiction between the pieces and their covers.

An outstanding example of Czech salon literature from the decorative point view is the music album Květomluva [The Speech of Flowers], Op. 30 composed by Jindřich Káan and published by F. A. Urbánek around 1880 . The cover included everything important to catch the potentional consumer. It consisted of florid and colorful motives, a smart typography and a poetical title. The compositions' titles as well as the composer's name were written in a fashionable French language. However, to make the album more understandable, common languages like German and Czech were also used. Florid decoration, bird motives and trilingual poems were used to adorn every particular piece.

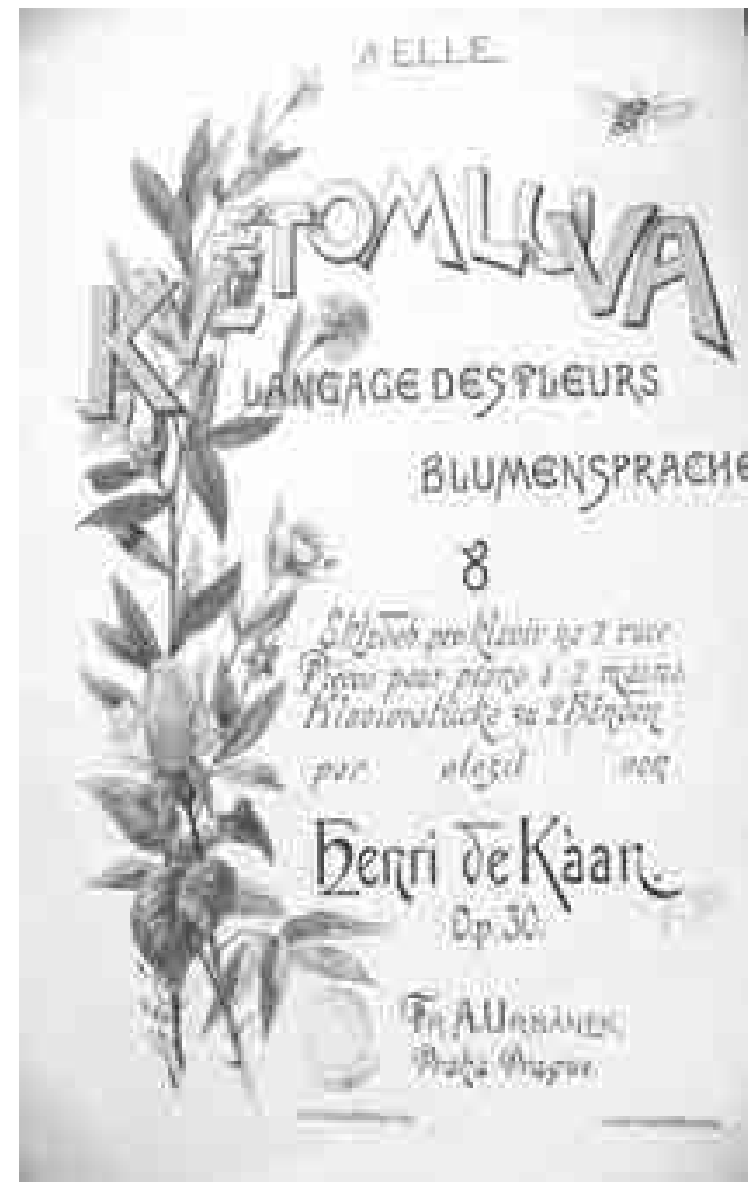

Album cover: Květomluva, Op. 30. U. 628 by Jindřich from Káan, Praha, F. A. Urbánek, [188?] 


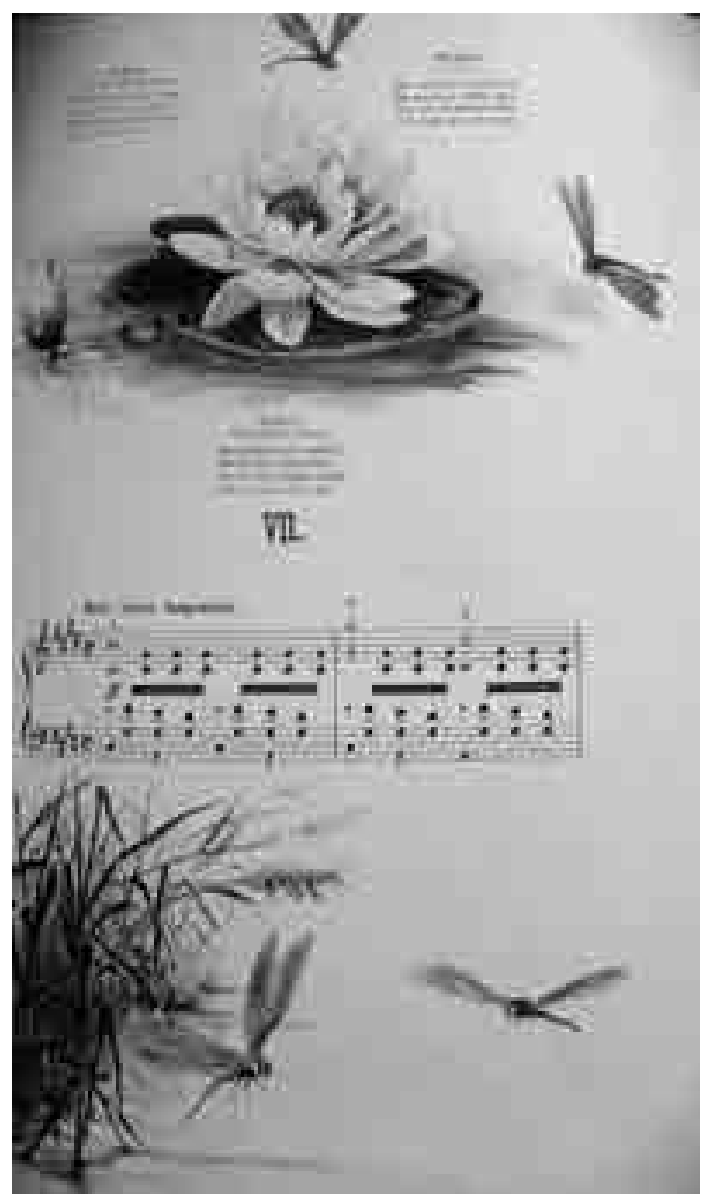

An excerpt from piano piece No. VII from the piano album Kvétomluva,

Op. 30. U. 628 by Jindřich from Káan, Praha, F. A. Urbánek, [188?]

Salon pieces are usually easily playable compositions. However, they might sound complicated thanks to tremolo and arpeggio play, abrupt dynamic and tempo changes, pseudo-virtuoso cadenzas and other features already mentioned. The two following quotes fittingly define the atmosphere of salon music: "Das müsste mindestens eine Schilderung des Weltschmerzes der Menschheit oder des Weltunterganges sein. Schließlich aber entpuppten sich die mit Vortragsanweisungen übersäten, aufs anspruchsvollste behandelten Salonstücke als höchst simple Kompositionen, als ein aufgeblähtes Nichts." "Die Flucht

8 Hans Christoph Worbs, "Salonmusik", in: Carl Dahlhaus (ed.), Studien zur Trivialmusik des 19. Jahrhunderts (Regensburg, 1967), p. 127. 
von der Realität, die Flucht in eine Welt unerreichbarer Wunschbilder, in ferne Länder und Zeiten, ist ein typisches Symptom der Salonmusik."9

Piano-playing became an important part of social communication in the $19^{\text {th }}$ century. The piano was also a significant medium which took part in the development of music reception. The market for salon music repertoire expanded rapidly, and thanks to the paraphrasing and transcription of musical pieces in less demanding forms many people became interested in music. Music started to be a business more than ever and market relationships were set up between music producers, composers and consumers. Salon music was highly criticized within the $19^{\text {th }}$ century precisely for these commercial goals and for a decline in the artistic level. Despite the negatives it is the duty of today's musicologists to accept this area of music as an important part of social and economic life in the $19^{\text {th }}$ century.

\section{Europäische und tschechische Salonklaviermusik in der zweiten Hälfte des 19. Jahrhunderts}

\section{Zusammenfassung}

Die Studie befasst sich mit dem Phänomen der massenhaft produzierten und herausgegebenen Gattung der Salonklaviermusik im europäischen und tschechischen Kontext. Im Bezug auf das erforschte Phänomen konzentriert sich die Studie auf die Aktivitäten des tschechischen Herausgebers František A. Urbánek, der eine Führungsposition im Gebiet der Herausgabe und der Propagierung der Salonmusik in Tschechischen Ländern besitzt.

\section{Evropská a česká salonní klavírní hudba druhé poloviny 19. století}

Shrnutí

Studie se zabývá fenoménem masově produkovaného a vydávaného žánru salonní klavírní hudby v evropském a českém kontextu. Sleduje zejména aktivity české nakladatelské firmy Františka A. Urbánka, frontmana v oblasti nakladatelské produkce a propagace salonní hudby v českých zemích.

\section{Keywords}

Piano miniatures; publishing house F. A. Urbánek; salon music.

9 Ibid., p. 127. 